\title{
Application of TOPSIS Method in Multi-Objective Optimization of the Grinding Process Using Segmented Grinding Wheel
}

\author{
D.D. Trunga,*, N.V. Thiena, N.-T. Nguyen ${ }^{a}$ \\ a Faculty of Mechanical Engineering, Hanoi University of Industry, Vietnam.
}

Keywords:

Segmented grinding wheel

Surface grinding

Surface roughness

Vibrations

MRR

Multi optimization

Taguchi

TOPSIS

* Corresponding author:

Do Duc Trung

E-mail: doductrung@haui.edu.vn

Received: 4 November 2020

Revised: 30 November 2020

Accepted: 23 December 2020

\begin{abstract}
A B S T R A C T
Using a segmented grinding wheel improves chip release and heat release condition out of the cutting zone, facilitates the introduction of coolant into the cutting zone, as well as increases the ability to clean the grinding wheel surface. Therefore, using segmented grinding wheel promises to improve the quality and efficiency of the machining process. This paper presents a study about the multi-objective optimization of grinding process using a segmented grinding wheel. The parameters that are shosen as the output criteria are the surface roughness, amplitudes of system vibrations in $X, Y, Z$ directions ( $A x, A y, A z)$, and the material removal rate (MRR). The experiments were performed in the surface grinding machine with the workpiece material of DIN 1.2379 steel and the grinding wheel material of aluminum oxide. The experimental matrix was designed using Taguchi method with nine experiment (orthogonal array L9) and with four input parameters (number of grooves, workpiece velocity, feed rate, and depth of cut). From the experimental data, the influence of input parameters on the output parameters were investigated. The TOPSIS method was applied to solve the multi-objective optimization problem. Then, the optimized set of input parameters was determined to ensure the minimum value of surface roughess, minimum values of three vibarion components, and to ensure the maximum value of MRR. Finally, the future research directions of this study were also proposed.
\end{abstract}

C 2021 Published by Faculty of Engineering

\section{INTRODUCTION}

In mechanical machining, grinding processes are often chose as the final machining method for the surface with high accuracy. As the requirements for the product accuracy and productivity of the grinding process are getting higher and higher, many scientists have developed many different methods of grinding such as grinding new materials (grinding Y3Al5012 (YAG) single crystals [1], grinding the Gallium gadolinium garnet (GGG) single crystals [2]); improvement of the efficiency of the grinding method by wrapping the outside of the grinding wheel a rubber cushion to minimize the formation of a hard air layer around the grinding wheel, which facilitates chip release and 
heat release and supply the lubricant solution to the cutting zone [3]; improve the cutting conditions of the grinding wheel, reduce the abrasion of the grinding wheel, as well as improve the machining accuracy and limit the rust on the surface of the parts by adding an substance into the grinding wheel (by impregnating method) such as Mo2S [4] material, sol - gel alumina and a synthetic organosilicon polymer - based impregnate [5]. Another research direction that is interested by many scientists is using the slotted and segmented grinding wheels. This research direction offers a promising solution in improve the quality and efficiency of the grinding process $[6,7]$.

In comparing with the conventional grinding wheels, using slotted grinding wheel could reduce the cutting heat by $40 \%$ to $80 \%$ [8]. Using segmented grinding wheel, the cutting force could be reduced by up to $30 \%$ in comparing with the case using conventional grinding wheels [9]. When using segmented grinding wheels, both surface roughness and cutting force were smaller value than ones when using conventional grinding wheel $[10,11]$. Some recommendations have also been proposed when using a slotted aluminum oxide grinding wheel as following: surface roughness will have a minimum value when the number of grooves on the grinding wheel were 18 (grooves) [12], the cutting force is minimized when the the grooves in the grinding wheel were 20 (grooves) [13]. The above studies show that using the segmented grinding wheel have more benefits that using the conventinal grinding wheels, However, these studies are mentioned to the comparison between using the segmented grinding wheels and using conventional grinding wheels. So, it is necessary to deeply investigate about the grinding technology using segmented grinding wheels.

Surface roughness was chosen for evaluation criterion of the efficiency of machining in general, and grinding in particular $[14,15]$. Research to find the solutions to reduce surface roughness when grinding with conventional grinding wheel has been published in many studies. However, up to now, it seems that there have been not many studies that were performed to investigate the surface roughness in grinding processes using segmented grinding wheels.

MRR is one of the most criterion to evaluate the quality of the cutting processes in general and grinding processes in particular. However, up to date, the studies about MRR using the segmented grinding wheel have been not mentioned.

In the grinding processes, the spindle vibration even in very small amplitudes, also have a significant influence on the depth of the cut of the grinding grain on the machining surface, thereby affecting grinding productivity, surface quality and influence on the uneven wear phenomeno of the grinding wheel $[8,16-18]$. The spindle vibration of the grinder consists of forced and spontaneous (self-vibrating) vibrations [19]. The forced vibration is transmitted by external factors. The factors causing forced vibration can be mentioned as grinding wheel imbalance, bearing error, assembly error, ect. [20]. Self-vibrating is the vibration that occurs during grinding, which is highly dependent on the uniformity of the work material, cutting conditions, and the grinding wheel properties [16,17]. In grinding process, the reduction of spontaneous vibrations is much more advantageous than that one of forced vibrations, this can be accomplished by changing some of the factors that affect on it, such as selection of the suitable cutting conditions, improvement of the clamp system, etc. [16,21]. However, up to date, it seems that the determination of the value of the cutting parameter to reduce the vibrations of the spindle of grinding machine when using a segmented grinding wheel has not been mentined by any studies.

Above analysis shows that the studies about surface roughness, MRR, and system vibration components when using the segmented are the new contributions while the studies about this technology are quite limitation.

Designing the experiental matrix according to the Taguchi method has some advantages. This method can be performed with the limitation of experiments but with the large number of the input parameters. Especial, this method is suitable with the unclear research subjects [22-24]. The grinding process using a segmented grinding wheel is a case in which the study subjects have not been clearly understood. Therefore, the application of the Taguchi method to design the experiments in this case is very suitable.

TOPSIS method that is the multi-objective optimization were successfully applied in many studies with different research fields [25-31]. However, so far, it seems that the application of 
TOPSIS method to solve the multi-objective optimization in grinding process using segmented grinding wheel have not been performed in any studies.

DIN 1.2379 steel is a tool steel that has a high carbon and chromium content. This steel has a high hardness and wear resistance, and it is often used to manufacture the cutting tools, parts such as stamping molds, bending knives, wood cutting tool, etc. In addition, this steel is often used to manufacture the parts requiring high wear resistance such as sliders, guide parts. When manufacturing these parts, the grinding method is often chosen as the final finishing method. From above analysis, in this study, TOPSIS method will be applied to solve the multi-objective optimization problem in the grinding process of DIN 1.2379 steel using a segmented grinding wheel. The experimental matrix will be designed according to the Taguchi method with four input parameters including the number of grooves in the grinding wheel, the workpiece velocity, the feed rate, and the depth of cut. The reason these four parameters were chosen as the input parameters when designing the experimental matrix because the number of grooves in the grinding wheel is a parameter that characterizes the difference between a segmented grinding wheel and a conventional grinding wheel, meanwhile, the remaining three parameters can be easily adjusted by the operator of the machine. The first purpose of this study is to determine the effect of the number of the grooves in the grinding wheel, workpiece velocity, feed rate, and depth of cut on the surface roughness, the technology system vibrations, and MRR. The second aim of this study is determination of optimal values of machining parameter to simultaneously ensure the minimum values of surface roughness and three vibration components, and maximum value of material removal rate.

\section{EXPERIMENTAL METHOD}

\subsection{Grinding machine and grinding wheel}

The grinding machine (APSG-820/2A) that was made in Taiwan was used to perform the experimental research. The machine is capable of infinitely level adjusting the workpiece velocity and the feed-rate through the hydraulic pump system. Cutting depth is adjusted by vernier with precision of $0.005 \mathrm{~mm}$ (each line of vernier is $0.005 \mathrm{~mm}$ ).

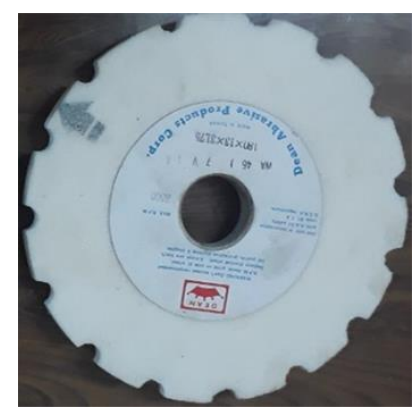

15 grooves

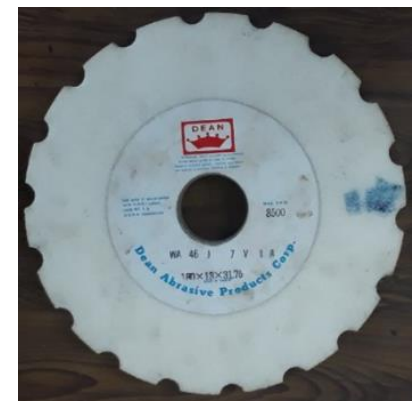

18 grooves

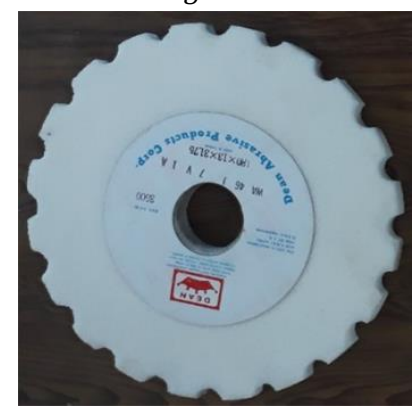

20 grooves

Fig 1. Experimental grinding wheels

Three aluminum oxide grinding wheels that were used with the sign of WA46J7V1A. The external diameter, thickness, and hole diameter of grinding wheels were $180 \mathrm{~mm}, 31.75 \mathrm{~mm}$, and 13 $\mathrm{mm}$, respectively. Three grinding wheels were grooved on the cylinder surface with number of the grooves of 15, 18, and 20, resepectively as shown in Fig 1. Each groove was semicircle with the diameter of $12 \mathrm{~mm}$ as shown in Fig.1. The central angle of each groove is 7.640 (Fig. 2).

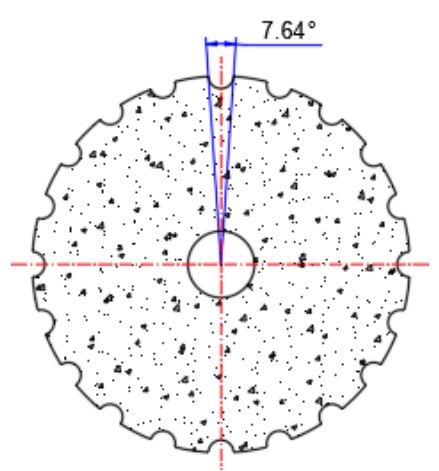

Fig 2. The central angle of groove 


\subsection{Workpiece material}

In this study, DIN 1.2379 steel was used to caried out the experiments. The chemical compositions of this steel are listed in Table 1. According several Standard, the equivalent sign of DIN 1.2379 steel are described in Table 2 . The properties of DIN 1.2379 were described in Table 3 . The dimensions of workpiece (length, width, and height) were $60 \mathrm{~mm}, 40 \mathrm{~mm}$, and $10 \mathrm{~mm}$, respectively. The workpieces were heat treated to achieve to hardness of 60HRC.

Table 1. Chemical composition of DIN 1.2379 steel

\begin{tabular}{|c|c|c|c|c|c|}
\hline $\mathrm{C}$ & $\mathrm{Si}$ & $\mathrm{Mn}$ & $\mathrm{Cr}$ & $\mathrm{Mo}$ & $\mathrm{V}$ \\
\hline 1.48 & 0.82 & 0.46 & 12.00 & 0.86 & 0.85 \\
\hline
\end{tabular}

Table 2. Equavalent symbol of DIN 1.2379 steel

\begin{tabular}{|c|c|c|c|c|c|}
\hline Germany & USA & China & Japan & France & England \\
\hline DIN & ASTM & GB & IJS & AFNOR & BS \\
\hline 1.2379 & D2 & CR12MOV1 & SKD11 & X160CrMoV12 & BD2 \\
\hline
\end{tabular}

Table 3. The properties of DIN 1.2379 steel

\begin{tabular}{|c|c|c|c|c|c|c|c|}
\hline $\begin{array}{c}\text { Density } \\
\left(\mathrm{g} / \mathrm{cm}^{3}\right)\end{array}$ & $\begin{array}{c}\text { Specific } \\
\text { heat } \\
\text { capacity } \\
\mathrm{J} /(\mathrm{Kg} \cdot \mathrm{K}) \\
\left(\text { at } 20^{\circ} \mathrm{C}\right)\end{array}$ & $\begin{array}{c}\text { Electrical } \\
\text { resistivity } \\
\mu \Omega \cdot \mathrm{m} \\
\left(\text { at } 20^{\circ} \mathrm{C}\right)\end{array}$ & $\begin{array}{c}\text { Elastic } \\
\text { modulus } \\
\mathrm{GPa} \\
\left(\mathrm{kN} / \mathrm{mm}^{2}\right)\end{array}$ & $\begin{array}{c}\text { Thermal } \\
\text { conductivity } \\
(\mathrm{W} / \mathrm{m} \cdot \mathrm{K}) \\
(\text { at } 200 \mathrm{C})\end{array}$ & $\begin{array}{c}\text { Coefficient } \\
\text { of thermal } \\
\text { expansion } \\
\left(10^{-6} / \mathrm{K}\right) \\
\left(\text { at } 20^{0}-\right. \\
\left.100^{\circ} \mathrm{C}\right)\end{array}$ & $\begin{array}{c}\text { Tensile } \\
\text { strength } \\
(\mathrm{MPa})\end{array}$ & $\begin{array}{c}\text { Yield } \\
\text { strength } \\
(\mathrm{MPa})\end{array}$ \\
\hline 7.7 & 460 & 0.65 & 210 & 16.7 & 10.5 & 920 & 420 \\
\hline
\end{tabular}

\subsection{Experimental design}

In this study, the Taguchi method was applied to design the experimental matix. Four input parameters that were chosen for each experiment were the number of grooves in cylinder surface of grinding wheel, workpiece velocity, feed-rate, and cutting depth. With these input parameters, Taguchi orthogonal array $L_{9}$ is the suitable array to design the experimental matrix. The experimental matrix was design by using the Minitab software, and this matrix was stored in Table 4.

Table 4. Taguchi orthogonal array L9 based OA design

\begin{tabular}{|c|c|c|c|c|c|c|c|c|}
\hline \multirow{2}{*}{ No. } & \multicolumn{5}{|c|}{ Code value } & \multicolumn{4}{c|}{ Actual value } \\
\cline { 2 - 9 } & $\mathrm{Z}$ & $v_{w}$ & $\mathrm{f}$ & $\mathrm{a}_{\mathrm{p}}$ & $\mathrm{Z}$ (groove) & $v_{w}(\mathrm{~m} / \mathrm{min})$ & $\mathrm{f}(\mathrm{mm} / \mathrm{stroke})$ & $\mathrm{a}_{\mathrm{p}}(\mathrm{mm})$ \\
\hline 1 & 1 & 1 & 1 & 1 & 15 & 5 & 2 & 0.005 \\
\hline 2 & 1 & 2 & 2 & 2 & 15 & 10 & 5 & 0.010 \\
\hline 3 & 1 & 3 & 3 & 3 & 15 & 15 & 8 & 0.015 \\
\hline 4 & 2 & 1 & 2 & 3 & 18 & 5 & 5 & 0.015 \\
\hline 5 & 2 & 2 & 3 & 1 & 18 & 10 & 8 & 0.005 \\
\hline 6 & 2 & 3 & 1 & 2 & 18 & 15 & 2 & 0.010 \\
\hline 7 & 3 & 1 & 3 & 2 & 20 & 5 & 8 & 0.010 \\
\hline 8 & 3 & 2 & 1 & 3 & 20 & 10 & 2 & 0.015 \\
\hline 9 & 3 & 3 & 2 & 1 & 20 & 15 & 5 & 0.005 \\
\hline
\end{tabular}

\subsection{Measurement system}

In this study the system vibrations were measured by a measurement system including the acceleration sensor Type 4525-B-001, the data processing box, and the PULSE software. The acceleration sensor was mounted on the protective cover plate of grinding wheel. Fig. 3 
presents the vibration measurement system of the grinding process. In each experiment, the system vibration components were measured from 6 to 10 seconds with about 5 to 8 machining strokes. The system vibarion components were determined in cutting zone of vibration diagrams. And the average values of vibration components in these zones were used to evaluate of system vibration components in grinding process.

Surface roughness wass measered by MITUTOYO-Surftest SJ-210 surface roughness tester (in Fig. 4). The evaluation length was fixed at $0.8 \mathrm{~mm}$. The surface roughness was measured perpendicular to the cutting velocity direction and repeated three times following three repeated times of each cutting test. The average value of surface roughness that were measured three consecutive times was used for analysis and evaluation.

In grinding process, $M R R$ depends on the many parameters such as cutting condition, tool variables, machine status, and workpiece variables. It is difficult to determine the values of MRR when considering all these parameters because many experiments must be performed with much time and cost [32]. In this study, $M R R$ is calculated by Eq. (1) $[16,17]$.

$$
M R R=v_{w} \times a_{p} \times b\left(\mathrm{~mm}^{3} / \mathrm{s}\right)
$$

Where:

$v_{w}$ is velocity of workpiece.

$a_{p}$ is depth of cut.

$b$ is wheel thickness.

So, from Eq. (1), for using the segmented grinding wheel, $M R R$ is calculated by Eq. (2).

$$
M R R=\frac{C-C_{S}}{C} v_{w} \times a_{p} \times b\left(\mathrm{~mm}^{3} / \mathrm{s}\right)
$$

\section{Where:}

$C$ is the perimeter of the normal grinding wheel, $C=2 \pi R$ ( $R$ is the grinding wheel radius).

$C_{s}$ is the total length of arcs at the grooved position, $C_{S}=Z . \alpha \cdot \frac{\pi \cdot R}{180}$ (In this study, $\alpha=7.64^{\circ}$ and $Z$ is the grooves in the grinding wheel).

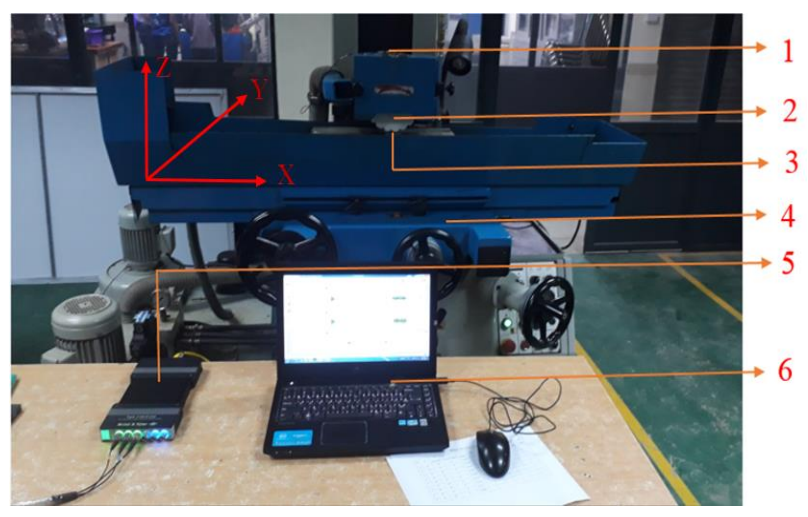

Fig 3: The experimental system, 1. Acceleration sensor, 2 Segmented grinding wheel, 3. Workpiece, 4. Grinding machine, 5. Signal processing system, 6. $\mathrm{PC}$ and software

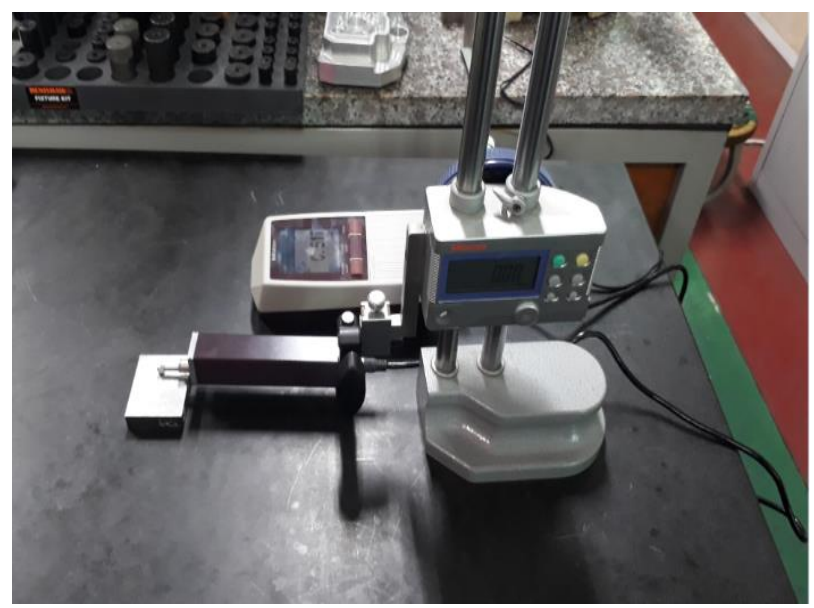

Fig 4: Measurement of the surface roughness by SJ210 surface roughness tester

\subsection{Grinding condition}

In addition to the values of the four input parameters that will be adjusted for each test as listed in Table 4, the grinding will be performed with fixed values of the following parameters: cutting velocity of $26 \mathrm{~m} / \mathrm{s}$, grinding wheel dressing depth of $0.01 \mathrm{~mm}$, grinding wheel dressing feed rate of $100 \mathrm{~mm} / \mathrm{min}$, using cooling lubricant oil of $10 \%$ emulsion- overflow with flow of $4.6 \mathrm{lit} / \mathrm{min}$.

\section{EXPERIMENTAL RESULTS AND DISCUSSION}

The experimental results were listed in Table 5 . From the results in this table, the infuence of input parameters on the $\mathrm{Ra}, \mathrm{Ax}, \mathrm{Ay}, \mathrm{Az}$ were investigated and presented from Fig 5 to Fig 8. 
Table 5. Experimental matrix and Results

\begin{tabular}{|r|c|c|c|c|c|c|c|r|r|}
\hline No. & $\begin{array}{c}\mathrm{Z} \\
\text { (groove) }\end{array}$ & $\begin{array}{c}v_{w} \\
(\mathrm{~m} / \mathrm{min})\end{array}$ & $\begin{array}{c}\mathrm{f} \\
(\mathrm{mm} / \mathrm{stroke})\end{array}$ & $\begin{array}{c}\mathrm{ap} \\
(\mathrm{mm})\end{array}$ & $\begin{array}{c}\mathrm{Ra} \\
(\mu \mathrm{m})\end{array}$ & $\begin{array}{c}\mathrm{Ax} \\
(\mu \mathrm{m})\end{array}$ & $\begin{array}{c}\text { Ay } \\
(\mu \mathrm{m})\end{array}$ & $\begin{array}{c}\text { Az } \\
(\mu \mathrm{m})\end{array}$ & $\begin{array}{c}\mathrm{MRR} \\
\left(\mathrm{mm}^{3} / \mathrm{s}\right)\end{array}$ \\
\hline 1 & 15 & 5 & 2 & 0.005 & 0.569 & 0.939 & 8.424 & 0.954 & 36.9236 \\
\hline 2 & 15 & 10 & 5 & 0.010 & 0.681 & 0.890 & 3.621 & 0.941 & 147.6944 \\
\hline 3 & 15 & 15 & 8 & 0.015 & 0.876 & 0.945 & 9.059 & 3.201 & 332.3125 \\
\hline 4 & 18 & 5 & 5 & 0.015 & 0.373 & 0.581 & 2.975 & 1.541 & 100.4250 \\
\hline 5 & 18 & 10 & 8 & 0.005 & 0.644 & 0.980 & 2.322 & 1.871 & 66.9500 \\
\hline 6 & 18 & 15 & 2 & 0.010 & 0.305 & 0.477 & 1.773 & 0.709 & 200.8500 \\
\hline 7 & 20 & 5 & 8 & 0.010 & 1.127 & 3.026 & 2.221 & 3.862 & 62.3519 \\
\hline 8 & 20 & 10 & 2 & 0.015 & 1.190 & 1.244 & 4.151 & 2.262 & 187.0556 \\
\hline 9 & 20 & 15 & 5 & 0.005 & 1.445 & 0.792 & 2.055 & 1.465 & 93.5278 \\
\hline
\end{tabular}

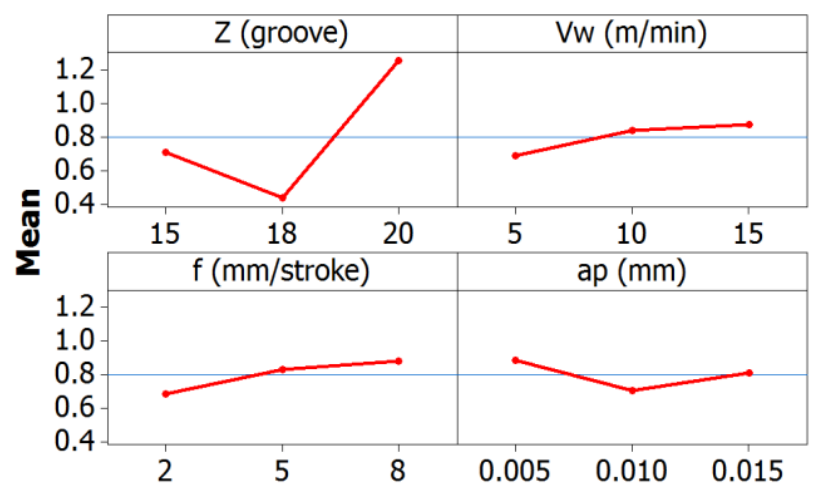

Fig. 5. Main effects plot for Ra

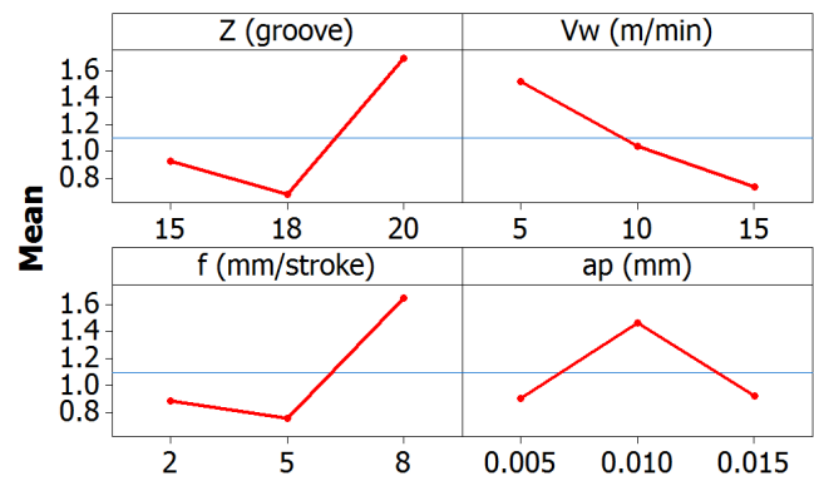

Fig. 6. Main effects plot for $\mathrm{Ax}$

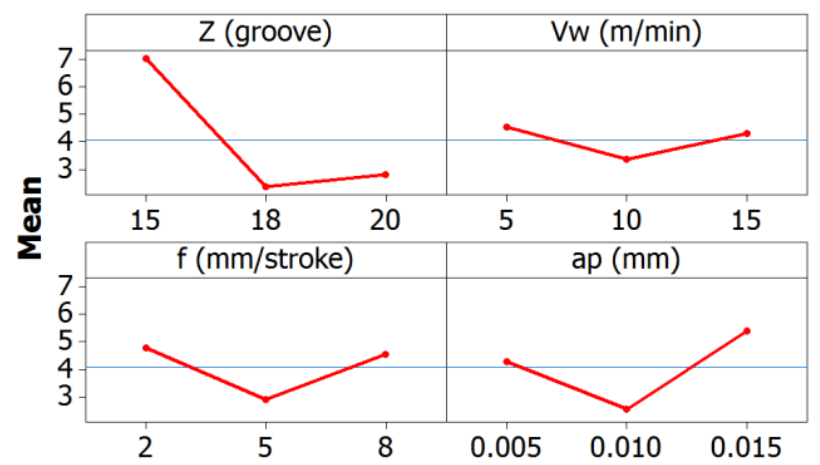

Fig. 7. Main effects plot for Ay

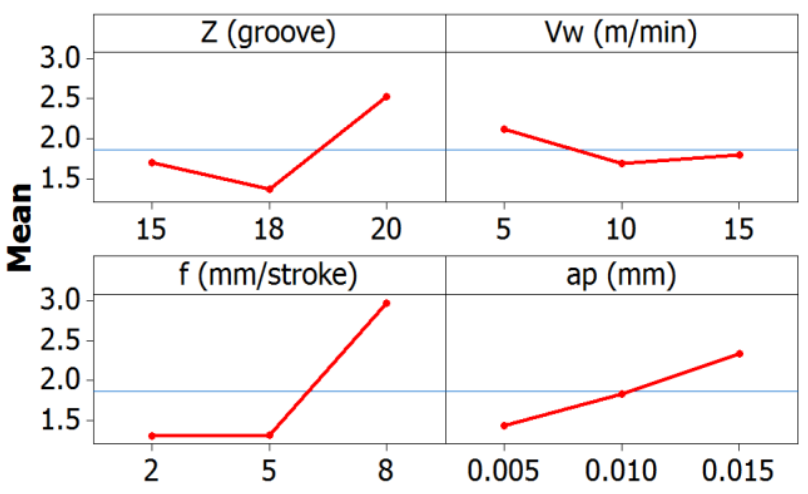

Fig. 8. Main effects plot for $\mathrm{Az}$

The results from these figures showed that:

- The number of the grooves in the grinding wheel has significant influence on the surface roughness. This issue can be explained that when the number of the grooves changes, it makes the changes of the friction between grinding wheel and workpiece surface. It changes the level of coolant introduction into the cutting zone and also changes the chip release and heat release ability during machining. These factors change the degree of scratching of the grinding grains on the workpiece surface and change the plastic deformation on the workpiece surface, thereby changing the surface roughness. The number of grooves in the grinding wheel also has a significant effect on the vibration components $(\mathrm{Ax}, \mathrm{Ay}$, and $\mathrm{Az}$ ) which the main reason for this phenomenon is that the change of the number of the grooves in the grinding wheel will create the changes of the continuous cutting conditions of the grinding wheel into the workpiece surface (incut and uncut), thereby affecting the cutting force components and system vibration components. 
- Workpiece velocity has significant influence on the $A x$, this issue can be explained that when changing the workpiece velocity, it makes the change of cutting force component in $\mathrm{x}$ direction, thereby it makes the change the vibration component in this direction.

- Feed rate also has the significant influence on the vibration components in all directions $(\mathrm{Ax}, \mathrm{Ay}$, and $\mathrm{Az}$ ). When feed rate changes, it creates the "stacking" phenomenon of the cuts of the grinding wheel into the workpiece surface, thereby it makes the effect on the cutting force components according to three directions. And, this is the reason of the change of the vibration components in three directions. Feed rate increases, surface roughness also increases, these are the results that were published by many authors $[16,17]$. However, in this study, the influnece degree of the feed rate on the surface roughness is quite small.

- Depth of cut has significant influence on the Az, when the depth of cut changes, the depth of the cuts of the grinding grains into the workpiece surface changes, it makes the changes of the cutting force component in $\mathrm{z}$ direction, so the vibration component in this direction also changes. Depth of cut has a negligible effect on the surface roughness and vibration components in $\mathrm{x}$ and $\mathrm{y}$ directions.

Because MRR is calculated by Eq. (2), so it is clear that MRR will increase when dereasing the number of the grooves in the grinding wheel, increasing the workpiece velocity, and increasing the depth of cut.

The results from Table 5 also show that: at the experiment number $6, \mathrm{Ra}, \mathrm{Ax}, \mathrm{Ay}, \mathrm{Az}$ were the smallest values in nine experimentals. However, at this experiemt, MRR was not the largest value in nine experiments. The largest value of MRR was obtained at the experiment number 3 . So, it is necessary to solve the multi-objective optimization problem to determine the machining parameters and the number of grooves with small value of surface roughness, small value of vibration component, and large value of MRR.

\section{MULTI-OBJECTIBVE OPTIMIZATION USING TOPSIS METHOD}

\subsection{TOPSIS method}

The experimental matrix that was designed using Taguchi method has many advantages as above presentation. However, when performing the optimization problem, if only using Taguchi method, only the single objection optimization problem is solved by analyzing the signal-to-noise ratio $\mathrm{S} / \mathrm{N}$. The multiobjective optimization problem can be solved when combining Taguchi method with other methods such as Grey relational analysis method (GRA) [36,37]. In this study, a combination method of Taguchi an TOPSIS was applied to solve the multi-objective optimization problem. TOPSIS method is widely used to solve the multi-objective optimization problems. This is the multiobjective decision method to determine the best solution from the given solutions. The steps to perform this methode are presented as following [33-35].

Sep 1: Arrange the solutions into the matrix form.

$$
X=\left[\begin{array}{cccc}
x_{11} & \ldots & x_{1 j} & x_{1 n} \\
x_{21} & \ldots & x_{2 j} & x_{2 n} \\
\ldots & \ldots & \ldots & \ldots \\
x_{i 1} & \ldots & x_{i j} & x_{i n} \\
\ldots & \ldots & \ldots & \ldots \\
x_{m 1} & \ldots & x_{m j} & x_{m n}
\end{array}\right]
$$

where: $x_{i j}$ is the criterion $\mathrm{j}$ in the solution $\mathrm{i} ; \mathrm{n}$ is the number of criterian; $m$ is the number of solutions.

Step 2: Calculate the transformation value of the criterion i in the solution $\mathrm{j}$ by Eq. (4).

$$
x_{i j}^{\prime}=\frac{x_{i j}}{\sqrt{\sum_{i=1}^{n} x_{i j}^{2}}}
$$

Step 3: Assign the weight $\mathrm{w}_{\mathrm{j}}$ for each criterion.

Step 4: Calculate the standardized matrix by Eq. (5).

$$
Y=w_{j} \cdot x_{i j}^{\prime}
$$

Step 5: Determine the best and worst solutions for each criterion by Eq. (6) and Eq. (7).

$$
\begin{aligned}
& A^{+}=\left\{y_{1}^{+}, y_{2}^{+}, \ldots, y_{j}^{+}, \ldots, y_{n}^{+}\right\} \\
& A^{-}=\left\{y_{1}^{-}, y_{2}^{-}, \ldots, y_{j}^{-}, \ldots, y_{n}^{-}\right\}
\end{aligned}
$$

where: $y_{j}^{+}$and $y_{j}^{-}$is the best and worst values of creterion $\mathrm{j}$, respectively. 
Step 6: Calculated $S_{i}^{+}$and $S_{i}^{-}$by Eq. (8) and Eq. (9).

$$
\begin{aligned}
& S_{i}^{+}=\sqrt{\sum_{j=1}^{n}\left(y_{i j}-y_{j}^{+}\right)^{2}} \mathrm{i}=1,2, \ldots, \mathrm{m} \\
& S_{i}^{-}=\sqrt{\sum_{j=1}^{n}\left(y_{i j}-y_{j}^{-}\right)^{2}} \mathrm{i}=1,2, \ldots, \mathrm{m}
\end{aligned}
$$

Step 7: Calculate $C_{i}^{*}$ by Eq. (10).

$$
\begin{gathered}
C_{i}^{*}=\frac{s_{i}^{-}}{S_{i}^{+}+S_{i}^{-}} \quad \mathrm{i}=1,2, \ldots, \mathrm{m} ; \\
0 \leq C_{i}^{*} \leq 1
\end{gathered}
$$

Step 8: Rank the solutions following the principle: The solution with the maximum value of $\mathrm{C}_{\mathrm{i}}^{*}$ is the best solution.

\subsection{Solving the multi-objective optimization problem}

For specific case of this study, the solution matrix of the cretieran is presented as following.

$$
X=\left[\begin{array}{ccccc}
R_{a 1} & A_{x 1} & A_{y 1} & A_{z 1} & M R R_{1} \\
R_{a 2} & A_{x 2} & A_{y 2} & A_{z 2} & M R R_{2} \\
\cdots & \ldots & \cdots & \ldots & \ldots \\
R_{a 8} & A_{x 8} & A_{y 8} & A_{z 8} & M R R_{8} \\
R_{a 9} & A_{x 9} & A_{y 9} & A_{z 9} & M R R_{9}
\end{array}\right]
$$

Applying the Eq. (4), the converted values of the criterion were calculted and listed in Table 6.

Applying the Eq. (5), the standardized matrix was determined and listed in Table 7 . In which the weight of five input parameters were selected to be the same $\left(w_{j}=0.2 ; j=1 \div 5\right)$.

From the data in Table 7 , the best and worst solutions were calculated by Eq. (6) and Eq. (7), and listed in Table 8.

The values of $\mathrm{S}_{\mathrm{i}}^{+}, \mathrm{S}_{\mathrm{i}}^{-}$, and $C_{i}^{*}$ were calculted by Eq. (8), Eq. (9), and Eq. (10), respectively, and presented in Table 9. In this table, the ranking of each solutions also was determinde.

Table 6. Converted values in TOPSIS

\begin{tabular}{|c|c|c|c|c|c|}
\hline No. & $\mathrm{X}_{\text {Ra }}$ & $\mathrm{X}_{\mathrm{Ax}}$ & $\mathrm{X}_{\text {Ay }}$ & $\mathrm{X}_{\mathrm{Az}}$ & $\mathrm{X}_{\mathrm{MRR}}$ \\
\hline 1 & 0.2154 & 0.2391 & 0.5814 & 0.1497 & 0.0760 \\
\hline 2 & 0.2578 & 0.2266 & 0.2499 & 0.1477 & 0.3039 \\
\hline 3 & 0.3317 & 0.2406 & 0.6253 & 0.5024 & 0.6838 \\
\hline 4 & 0.1412 & 0.1479 & 0.2053 & 0.2419 & 0.2067 \\
\hline 5 & 0.2438 & 0.2495 & 0.1603 & 0.2936 & 0.1378 \\
\hline 6 & 0.1155 & 0.1215 & 0.1224 & 0.1113 & 0.4133 \\
\hline 7 & 0.4267 & 0.7705 & 0.1533 & 0.6061 & 0.1283 \\
\hline 8 & 0.4505 & 0.3168 & 0.2865 & 0.3550 & 0.3849 \\
\hline 9 & 0.5471 & 0.2017 & 0.1418 & 0.2299 & 0.1925 \\
\hline
\end{tabular}

Table 7. Standardized matrix

\begin{tabular}{|c|c|c|c|c|c|}
\hline No. & $\mathrm{Y}_{\mathrm{Ra}}$ & $\mathrm{Y}_{\mathrm{Ax}}$ & $\mathrm{Y}_{\mathrm{Ay}}$ & $\mathrm{Y}_{\mathrm{Az}}$ & $\mathrm{Y}_{\mathrm{MRR}}$ \\
\hline 1 & 0.0431 & 0.0478 & 0.1163 & 0.0299 & 0.0152 \\
\hline 2 & 0.0516 & 0.0453 & 0.0500 & 0.0295 & 0.0608 \\
\hline 3 & 0.0663 & 0.0481 & 0.1251 & 0.1005 & 0.1368 \\
\hline 4 & 0.0282 & 0.0296 & 0.0411 & 0.0484 & 0.0413 \\
\hline 5 & 0.0488 & 0.0499 & 0.0321 & 0.0587 & 0.0276 \\
\hline 6 & 0.0231 & 0.0243 & 0.0245 & 0.0223 & 0.0827 \\
\hline 7 & 0.0853 & 0.1541 & 0.0307 & 0.1212 & 0.0257 \\
\hline 8 & 0.0901 & 0.0634 & 0.0573 & 0.0710 & 0.0770 \\
\hline 9 & 0.1094 & 0.0403 & 0.0284 & 0.0460 & 0.0385 \\
\hline
\end{tabular}

Table 8. The best and worst solutions

\begin{tabular}{|c|c|c|c|c|c|}
\hline & $\mathrm{Ra}$ & $\mathrm{Ax}$ & $\mathrm{Ay}$ & $\mathrm{Az}$ & $\mathrm{MRR}$ \\
\hline $\mathrm{A}+$ & 0.0231 & 0.0243 & 0.0245 & 0.0223 & 0.1368 \\
\hline $\mathrm{A}-$ & 0.1094 & 0.1541 & 0.1251 & 0.1212 & 0.0152 \\
\hline
\end{tabular}


Table 9. The values in TOPSIS

\begin{tabular}{|c|c|c|c|c|}
\hline No. & $\mathrm{Si}^{+}$ & $\mathrm{Si}^{-}$ & $\mathrm{C}_{\mathrm{i}}$ & Ranking \\
\hline 1 & 0.1556 & 0.1552 & 0.4994 & 2 \\
\hline 2 & 0.0879 & 0.1769 & 0.6680 & 6 \\
\hline 3 & 0.1366 & 0.1682 & 0.5519 & 3 \\
\hline 4 & 0.1006 & 0.1875 & 0.6507 & 4 \\
\hline 5 & 0.1210 & 0.1651 & 0.5771 & 1 \\
\hline 6 & 0.0541 & 0.2208 & 0.8031 & 9 \\
\hline 7 & 0.2071 & 0.0980 & 0.3212 & 7 \\
\hline 8 & 0.1142 & 0.1398 & 0.5504 & 5 \\
\hline
\end{tabular}

The calculated results from Table 9 showed that the solution 6 had the largest value of $\mathrm{C}_{6}$. So, this solution was the best solution in 9 solutions. These optimal values of groove number, workpiece velocity, feed rate, and depth of cut were 18 grooves, $15 \mathrm{~m} / \mathrm{min}, 2 \mathrm{~mm} /$ stroke, and $0.01 \mathrm{~mm}$, respectively. Using these optimal values of the input parameters, the surface roughness, vibration amplitudes in $\mathrm{X}, \mathrm{Y}, \mathrm{Z}$ directions were quite small $(0.305 \mu \mathrm{m}, 0.477 \mu \mathrm{m}, 1.773 \mu \mathrm{m}, 0.709$ $\mu \mathrm{m}$, respectively) while the material removal rate was quite large $\left(200.85 \mathrm{~mm}^{3} / \mathrm{s}\right)$. So, it can be said that in overall evaluating the grinding process through simultaneously 5 output parameters including surface roughness, three vibration components, and MRR, the solution number 6 was the best solution.

\section{CONCLUSION}

In this study, the experimental research was performed in grinding process of DIN 1.2379 steel using segmented grinding wheel with the groove number in the grinding wheel of 15,18 , and 20 and with the centeral angle of each groove of 7.640. Taguchi method was used to design the experimental matrix and the TOPSIS was applied to solve the multi-objective optimization problem. The conclusions of this study were drawn as follows:

- The number of grooves in the grinding wheel has the significant influence on the surface roughness and the vibraiton components $(\mathrm{Ax}$, $\mathrm{Ay}$, and $\mathrm{Az}$ ); workpiece velocity has big influence on the $A x$; feed rate has significant influence on the three vibration components $A x$, $\mathrm{Ay}$, and Az; depth of cut has significant influence on the Az, depth of cut has a negligible effect on the surface roughness and vibration components in $\mathrm{x}$ and $\mathrm{y}$ directions; MRR will increase when dereasing the number of the grooves in the grinding wheel, increasing the workpiece velocity, and increasing the depth of cut.

- The optimal values of groove number, workpiece velocity, feed rate, and depth of cut, were 18 grooves, $15 \mathrm{~m} / \mathrm{min}, 2 \mathrm{~mm} /$ stroke, and $0.01 \mathrm{~mm}$, respectively.

- Using these optimal values of the input parameters, the surface roughness, vibration amplitudes in $\mathrm{X}, \mathrm{Y}, \mathrm{Z}$ directions were quite small $(0.305 \mu \mathrm{m}, 0.477 \mu \mathrm{m}, 1.773 \mu \mathrm{m}, 0.709$ $\mu \mathrm{m}$, respectively) while the material removal rate was quite large $\left(200.85 \mathrm{~mm}^{3} / \mathrm{s}\right)$.

The multi-objective optimization problem of the grinding process when considering the influence of more input paramters such as the dressing parameters, the grinding grain types, grain size of grinding wheel, the dimension of grooves, and so on are the extending reseach directions next time.

\section{Acknowledgment}

The authors thank Faculty of Mechanical Engineering, Hanoi University of Industry for the support during the implementation of this study.

\section{REFERENCES}

[1] C. Li, X. Li, Y. Wu, F. Zhang, H. Huang, Deformation mechanism and force modelling of the grinding of $Y A G$ single crystals, International Journal of Machine Tools and Manufacture, vol. 143, pp. 2337, 2019, doi: 10.1016/j.ijmachtools.2019.05.003 
[2] C. Li, Y. Wu, X. Li, L. Ma, F. Zhang, H. Huang, Deformation characteristics and surface generation modelling of crack-free grinding of GGG single crystals, Journal of Materials Processing Tech, vol. 279, pp. 1-15, 2019, doi: 10.1016/j.jmatprotec.2019.116577

[3] S. Guha, P. Protim Das, S. Chakraborty, Improvement in the performance with less stiff air layer formation around the rubber tube-pasted grinding wheel, Proceedings of the Institution of Mechanical Engineers, Part C: Journal of Mechanical Engineering Science, vol. 233, iss. 15, pp. 51755189, 2019, doi: 10.1177/0954406219844534

[4] W. Kapłonek, K. Nadolny, M. Sutowska, M. Mia, D. Y. Pimenov, M. K. Gupta, Experimental Studies on MoS2-Treated Grinding Wheel Active Surface Condition after High-Efficiency Internal Cylindrical Grinding Process of INCONEL $₫$ Alloy 718, Micromachines, vol. 10, iss. 4, pp. 1-19, 2019, doi: 10.3390/mi10040255

[5] W. Kapłonek, K. Nadolny, K. Rokosz, J. Marciano, M. Mia, D. Y. Pimenov, O. Kulik, M. K. Gupta, Internal Cylindrical Grinding Process of INCONEL® Alloy 600 Using Grinding Wheels with Sol-Gel Alumina and a Synthetic Organosilicon Polymer-Based Impregnate, Micromachines, vol. 11, iss. 2, pp. 1-18, 2020, doi: 10.3390/mi11020115

[6] W.C. Herman, Segmental grinding wheel, US Patent, US2032362A, 1936.

[7] T. Nguyen, L.C. Zhang, Modelling of the mist formation in a segmented grinding wheel system, International Journal of Machine Tools and Manufacture, vol. 45, iss. 1, pp. 21-28, 2005, doi: 10.1016/j.ijmachtools.2004.06.019

[8] K.W. Lee, P.K. Wong, J.H. Zhang, Study on the grinding of advanced ceramics with slotted diamond wheels, Journal of Materials Processing Technology, vol. 100, iss. 1-3, pp. 230-235, 2000, doi: 10.1016/S0924-0136(00)00403-9

[9] D.X. Jin, Z. Meng, Research for discontinuous grinding wheel with multi- porous grooves, Key Engineering Materials, vol. 259, pp. 117-121, 2004, doi: 10.4028/www.scientific.net/KEM.259-260.117

[10] X. Fan, M. Miller, Force analysis for grinding with segmental wheels, Machining Science and Technology, vol. 10, iss. 4, pp. 435-455, 2006, doi: 10.1080/10910340600996142

[11] P.B. Handigund, M. H. Miller, Abrasive Wear and Forces in Grinding of Silicon Carbide, Michigan Technological University, Houghton, MI, 2001.

[12] N.T. Phuong, N.T.P. Giang, N.T. Dong, A Research on the Affect of Technologycal Parameters on Cutting Temperature When Machining use Segmented Grinding Wheel, International Journal of Electronics Communication and Computer Engineering, vol. 8, iss.3, pp. 208-212, 2017.
[13] N.T. Phuong, N.T.P. Giang, N.T. Dong, A research on the effect of cutting parameters on cutting force in flat grinding using segmentd grinding wheel, Vietnam Journal of Science and Technology, vol. 55, no. 6, pp. 793-802, 2017, doi: 10.15625/2525-2518/55/6/8961

[14] K. Ohashi, K. Tan, T. Ashida, S. Tsukamoto, Quick On-Machine Measurement of Ground Surface Finish Avaiable for Mass Production Cylindrical Grinding Process, International Journal of Automation Technology, vol. 9, no. 2, pp. 176183, 2015, doi: 10.20965/ijat.2015.p0176

[15] Y. Takaya, In-Process and On-Machne Measurement of Machining Accuracy for Process and Product Quality Management: A Review, International Journal of Automation Technology, vol. 8, no. 1, pp. 4-19, 2014, doi: 10.20965/ijat.2014.p0004

[16] I.D. Marinescu, M.P. Hitchiner, E. Uhlmann, W.B. Rowe, I. Inasaki, Handbook of machining with grinding wheels, CRC Press, 2006

[17] S. Malkin, C. Guo, Grinding technology: Theory and Applications of Machining with Abrasives (2nd Edition), New York: Industrial Press, 2008.

[18] Y. Cao, J. Guan, B. Li, X. Chen, J. Yang, C. Gan, Modeling and simulation of grinding surface topography considering wheel vibration, The International Journal of Advanced Manufacturing Technology, vol. 66, pp. 937-945, 2013, doi: 10.1007/s00170012-4378-7

[19] S. Malkin, Grinding of metals: theory and applications, Journal of Applied Metalworking, vol. 3, pp. 95-109, 1984, doi: 10.1007/BF02833688

[20] R. Aini, H. Rahnejat, R. Gohar, A five degrees of freedom analysis of vibrations in precision spindles, International Journal of Machine Tools Manufacture, vol. 30, iss. 1, pp. 1-18, 1990, doi: 10.1016/0890-6955(90)90037-J

[21] T. Liu, Z. Deng, L. Lv, S. She, W. Liu, C. Luo, Experimental Analysis of Process Parameter Effects on Vibrations in the High-Speed Grinding of a Camshaft, Strojniški vestnik - Journal of Mechanical Engineering, vol. 66, iss. 3, pp. 175183, 2020, doi: 10.5545/sv-jme.2019.6294

[22] M.S. Phadke, Quality Engineering Using Robust Design, Printice Hall, 1989.

[23] S.K. Karna, R.V. Singh, R. Sahai, Application of Taguchi Method in Indian Industry, International Journal of Emerging Technology and Advanced Engineering, vol. 2, iss. 11, pp. 387-391, 2012.

[24] S. K. Karna, R. Sahai, An Overview on Taguchi Method, International Journal of Mathematical, Engineering and Management Sciences, vol. 1, pp. 11-18, 2012. 
[25] A. R. Wisnuadi, R. W. Damayanti, E. Pujiyanto, Multi Response Optimization of Internal Grinding Process Parameters for Outer Ring using Taguchi Method and PCR-TOPSIS, AIP Conference Proceedings, vol. 1931, iss. 1, pp. 1-6, 2018, doi: 10.1063/1.5024088

[26] N. H. Phan, Conformity assessment of TopsisTaguchi integration for multi-characteristics optimization of process parameters in electrical discharge machining, Science and technology development journal: Engineering \& technology, vol.1, no. 2, pp. 42-49, 2018.

[27] P. Umamaheswarrao, D.R. Raju, KNS Suman, B.R. Sankar, Topsis based optimization of process parameters while hard turning of AISI 52100 steel, Acta Mechanica Malaysia (AMM), vol. 2, iss. 2, pp. 28-31, 2019, doi: 10.26480/amm.02.2019.28.31

[28] J. Kumar, R.K. Verma, Experimental investigations and multiple criteria optimization during milling of Graphene Oxide (GO) doped epoxy/CFRP composites using TOPSIS-AHP hybrid module, FME Transactions, vol. 48, iss.3, pp. 628-635, 2020, doi: $10.5937 /$ fme2003628K

[29] P.B. Sagar, P.D. Pantanwane, B. Rajiv, Optimisation of hard turning of M42 steel using PCR-Topsis method, in 5th International \& 26th All India Manufacturing Technology, Design and Research Conference, AIMTDR 12 $2^{\text {th }}-14^{\text {th }}$ December, 2014, IIT Guwahati, Assam, India, vol. 325, pp. 1-6.

[30] A. Thanikasalam, J. Elanchezhian, Multi Response Optimization of Process Parameters in Cryogenic Co2 Grinding Using TOPSIS Method, International Journal of Advance Science and Technology, vol. 29, iss. 10S, pp. 6927-6937, 2020.

[31] S.S. Sankar, M.V. Kumar Reddy, Experimental Investigation and Optimization of EDM Process parameters on Al6061 by using TOPSIS and comparison with Genetic Algorithm, International Journal of Engineering and Advanced Technology, vol. 8, iss. 2S2, pp. 76-83, 2019.

[32] N.C. Deresse, V. Deshpande, I.W.R. Taifa, Experimental investigation of the effects of process parameters on material removal rate using Taguchi method in external cylindrical grinding operation, Engineering Science and Technology, an International Journal, vol. 23, iss. 2, pp. 405-420, doi: 10.1016/j.jestch.2019.06.001
[33] T. Temucin, H. Tozan, O. Vayvay, M. Harnicarova, J. Valicek, A fuzzy based decision model for nantraditional machining process selection, International Journal of Advanced Manufacturing Technology, vol. 70, pp. 22752282, 2014, doi: 10.1007/s00170-013-5474-z

[34] S. J. Chen, C. L. Hwang, Fuzzy multiple attribute decision making methods and applications, Springer, 1992, doi: 10.1007/978-3-642-46768-4

[35] C.L. Hwang, K. Yoon, Multiple attribute decision making methods and applications, Springer, 1981, doi: 10.1007/978-3-642-48318-9

[36] A.M. Khan, M. Jamil, M. Mia, D.Y. Pimenov, V.R. Gasiyarov, M.K. Gupta, N. He, Multi-Objective Optimization for Grinding of AISI D2 Steel with Al203 Wheel under MQL, Materials, vol. 11, iss. 11, pp. 1-20, 2018, doi: 10.3390/ma11112269

[37] D.Y. Pimenov, A.T. Abbas, M.K. Gupta, I.N. Erdakov, M.S. Soliman, M.M. El Rayes, Investigations of surface quality and energy consumption associated with costs and material removal rate during face milling of AISI 1045 steel, The International Journal of Advanced Manufacturing Technology, vol. 107, pp. 35113525, 2020, doi: 10.1007/s00170-020-05236-7

\section{Nomenclature}

\section{Z: The number of grooves in cylinder surface of grinding} wheel.

$v_{w}$ : Velocity of workpiece.

$f$ : Feed rate.

$a_{p}$ : Depth of cut.

b: Wheel thickness.

Ra: Surface roughness (Roughness average).

MRR: Material removal rate.

$A x, A y, A z:$ The amplitudes of system vibrations in $X, Y, Z$ directions.

C: Is the perimeter of the normal grinding wheel.

$C_{s}$ : Is the total length of arcs at the grooved position. 